invention was first shown to the English public. M. Lumière was present and was the recipient of a gold fountain pen and pencil as a memento of the occasion. The events of forty years before were re-enacted and copies of some of the films then shown were screened. In one or two cases the original projector was used, and the quality and steadiness of the pictures were remarkable. Among other films shown were early news reels and examples illustrating the stages in the development of motion picture technique and in. vention, including two short colour sequences. Fyvie Hall contained exhibits, many of them from the collection of Mr. Will Day, illustrative of the history of cinematography, ranging from moving lantern slides of one hundred years ago to examples of the most modern motion picture cameras and projection equipment. The exhibition remained open to the public and the films were shown for three days.

\section{Utilisation of Fuel}

TECHNICAL problems of the utilisation of fuel have long been a popular subject of discussion, but the troubles of the coal trade have recently evoked an unusual number of contributions. Sir Harold Hartley, in a paper before the Institution of Chemical Engineers, examined our "National Coal Resources", Sir Frank Smith discussed "Coal, Power and Smoke" before the Junior Institution of Engineers, Sir William Larke addressed the Fuel Luncheon Club, an anonymous "Observer" has recently issued a pamphlet on "Miners, Owners and Mysteries", and Mr. O. W. Roskill discussed before the Institute of Fuel the "Co-ordination of National Fuel and Power Supplies", while chairmen of public utility companies have much to say about coal when addressing their shareholders at this season. The reader will find considerable repetition in these discussions, but cannot escape the impression of the extreme com. plexity of the problems.

THE technical problems involved, though naturally complicated, are obviously capable of solution, and indeed would present no fundamental difficulty if national fuel services were being planned $a b$ initio. The more difficult questions arise from the necessity for reconciling conflicting financial and industrial interests, conflicting local interests, conflicting national interests such as economics and defence, the promotion of fuel economy and the provision of employment. Most of the proposals for promoting efficiency or economy would involve a reduction, at least for a time, of labour or employment for some, and the adjustment of the coal industry to a new level of stability will clearly be long and difficult. Mr. Roskill, after surveying all the coal-using industries, advocates a concentration of the Ministry of Mines, Transport and the relevant section of the Board of Trade, into a new Ministry of Fuel, the chief object of which would be to reconcile now competing interests of the fuel industries. The "Observer", apparently an engineer, believes that the coal trade should adopt the methods of the engineering industry in its treatment of labour problems.

\section{The Municipal Smoke Problem}

THE problem of air pollution by smoke has long engaged the attention of scientific workers, but only latterly has the public realised that its solution is of first-class importance to the civil life of the community. The presence of pollutants in the atmosphere is proof of wastage of fuel. If fuel is properly and completely burned, the maximum amount of heat will be obtained without smoke, whereas if it is incompletely burned, smoke will be produced. The ultimate source of all heat, or energy, is the sun, which in its direct form of sunshine should be accessible, and in its indirect form of fuel should be conserved. Air pollutants must therefore be attacked for the two-fold reason that they blot out the sunshine, and are produced only by wastage of fuel. In November last, at the request of members of the General Science Club of teachers in the Pittsburgh High Schools, who considered it essential for all students to have a rudimentary knowledge of fuels and their uses, Messrs. H. B. Meller and L. B. Sisson, of the Mellon Institute of Industrial Research, issued a pamphlet on the subject. Therein are listed the fuels most commonly used, namely, coal (anthracite, semi-bituminous and bituminous), coke, oil and gas (natural and manufactured). Data are adduced to show in as compact a form as possible of what these fuels are composed, how and why they burn, what products they give off and whether such products exert a beneficial or deleterious effect. Finally, indication is given of the efforts which have been made to date to rid the atmosphere of pollutants. The booklet is in effect an exposition of facts which every citizen should know if he is to help in the solution of the problem of obtaining maximum heat from fuel with minimum air pollution.

\section{The Indian Academy of Sciences}

Is his presidential address in January of last year to the premier Indian academy, the National Institute of Sciences of India, Sir Lewis Fermor welcomed the formation in Bangalore of the Indian Academy of Sciences, which owes its inception to the energies of Sir Venkata Raman. The Indian Academy of Sciences is already well known through the medium of its publications, and in December last Sir Venkata Raman delivered his presidential address at the first annual meeting, which was held in Bombay. In this he clearly set forth the aims of the Academy. and at the same time he appealed for funds to enable it to continue and extend its activities, and also for the erection of a suitable building for which the generosity of the Maharajah of Mysore had already provided a site adjacent to the Indian Institute of Science. It is somewhat surprising to find in the address no reference to the National Institute of Sciences with which, from Sir Lewis Fermor's remarks, we had gathered it was to co-operate. We trust that the absence of such reference does not imply that this co-operation has ceased. If the growing body of scientific thought in India is to exercise that influence on the government of the country, which is its due, or if it is to be adequately repre- 